\title{
Тканевые биостимуляторы
}

\section{АНТИКЛАСТОГЕННАЯ АКТИВНОСТЬ АМИНОСЕЛЕТОНА ПРИ ВОЗДЕЙСТВИИ ЦИКЛОФОСФАМИДА НА КОСТНЫЙ МОЗГ МЫШЕЙ}

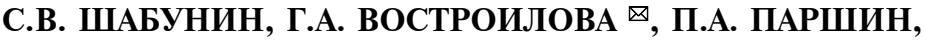 \\ Д.И. ШАБАНОВ, Н.А. ХОХЛОВА
}

Тканевый препарат аминоселетон, разработанный во Всероссийском научно-исследовательском ветеринарном институте патологии, фармакологии и терапии, получен из селезенки крупного рогатого скота методом криогенного фракционирования. Ранее были показаны адаптогенные, мембраностабилизирующие, стресс-протекторные, антиоксидантные и иммуномодулирующие свойства аминоселетона. В настоящей работе впервые выявлено антикластогенное действие тканевого препарата аминоселетон по отношению к клеткам костного мозга мышей, подвергнутых воздействию экспериментального мутагена. Кроме того, было показано сохранение цитогенетической стабильности и митотической активности в клетках костного мозга здоровых животных при применении исследуемого препарата. Цель работы - оценка влияния аминоселетона на цитогенетическую стабильность клеток костного мозга здоровых и подвергнутых действию экспериментального мутагена мышей, а также выявление антимутагенного свойства препарата применительно к генотоксическому эффекту циклофосфамида с использованием микроядерного теста. Эксперименты проводили на беспородных белых мышах (Mus albus officinarum), которые были разделены на группы, подвергшиеся следующим воздействиям: введение внутримышечно стерильного изотонического раствора хлорида натрия в объеме 0,2 мл (негативный контроль, $n=12$ ); инъекция внутрибрюшинно 0,2 мл циклофосфамида (ЦФ, «Baxter Oncology GmbH», Германия) в дозе 20,0 мг/кг массы тела (позитивный контроль, $n=12$ ); внутримышечное однократное введение 0,2 мл аминоселетона в терапевтической дозе 0,5 мл/кг $(n=12)$; внутримышечная однократная инъекция 0,2 мл аминоселетона в 10-кратной терапевтической дозе 5,0 мл/кг $(n=12)$; внутримышечное однократное введение 0,2 мл аминоселетона в дозе 0,5 мл/кг, через 72 ч внутрибрюшинное введение 0,2 мл ЦФ в дозе 20,0 мг/кг $(n=6)$; внутримышечное введение 0,2 мл аминоселетона в дозе 0,5 мл/кг 5кратно с интервалом 24 ч, через 72 ч после пятой инъекции внутрибрюшинное введение ЦФ аналогично животным других групा $(n=6)$. Для определения количества хромосомных аберраций в костном мозге за 2,5 ч до эвтаназии мышам делали внутрибрюшинную инъекцию 0,025 \% колхицина («ПанЭко», Россия). Из бедренных костей с помощью буферного раствора Хенкса $(\mathrm{pH} 7,4)$ вымывали клетки костного мозга, инкубировали суспензию клеток в 0,075 молярном гипотоническом растворе $\mathrm{KCl}$, затем фиксировали клетки с помощью охлажденного до $4{ }^{\circ} \mathrm{C}$ ацетоалкоголя и окрашивали по Романовскому-Гимзе. Оценивали митотический индекс (МИ) по числу делящихся клеток на 1000 клеток костного мозга. Подсчитывали число клеток с хромосомными аберрациями в 100 метафазных пластинках на каждое животное. Учитывали одиночные и парные фрагменты, обмены и ахроматические пробелы (гепы), а также клетки с множественными патологиями. Для изучения частоты микроядер (микроядерный тест) полихроматофильных эритроцитов (ПХЭ) полученные клетки костного мозга добавляли к 1 \% раствору альбумина в буферном растворе Хенкса $($ рН 7,4$)$ и наносили на предметные стекла, далее препараты высушивали, фиксировали метанолом и окрашивали по Романовскому-Гимзе. Определяли частоту микроядер на 1000 ПХЭ, всего изучали 2000 ПХЭ на животное. Также учитывали долю ПХЭ на 500 нормохромныХ эритроцитов (НЭ) и ПХЭ. Частота хромосомных аберраций и микроядер при введении препарата в исследуемых дозах статистически значимо не отличалась от таковой у животных из групाы негативного контроля, которая составила соответственно $1,0 \pm 0,40$ и 0,2 $\pm 0,06 \%$. Введение аминоселетона также не оказывало влияния на митотический индекс клеток костного мозга экспериментальных животных. Курсовое введение аминоселетона снижало кластогенное действие циклофосфамида, оцениваемое по количеству микроядер в ПХЭ костного мозга, с $2,3 \pm 0,21 \%$ у мышей из группы позитивного контроля до $1,0 \pm 0,40 \%$ у животных после курса инъекций аминоселетона. То есть наблюдалось снижение кластогенной активности циклофосфамида на 51,3 \%, что, вероятно, было связано с коррекцией исследуемым препаратом прооксидантно-антиоксидантной системы организма животных. Снижение числа микроядер, индуцируемых циклофосфамидом в ПХЭ, свидетельствовало о наличии у аминоселетона антикластогенного потенциала.

Ключевые слова: аминоселетон, циклофосфамид, мутагенность, антикластогенные свойства, микроядра, хромосомные аберрации, костный мозг, белые мыши, полихроматофильные эритроциты.

Снижение негативного влияния стресс-факторов на организм животных посредством использования препаратов-адаптогенов - одно из 
направлений исследований в ветеринарной медицине (1). Среди лекарственных средств такого класса можно выделить группу препаратов, имеющих в составе вытяжки экстракты органов и тканей животных. Поскольку селезенка служит источником значительного количества цитокинов различных типов, она стала основой для нескольких отечественных и зарубежных органопрепаратов (2). Для многих из них показаны иммуномодулирующие и адаптогенные свойства $(3,4)$. Однако видовые и возрастные параметры животных, от которых получены органы, а также технологические особенности обработки сырья при производстве препарата могут в некоторой степени изменить конечный химический состав лекарственного средства и, следовательно, повлиять на его биологическую активность и терапевтическую эффективность (4).

Во Всероссийском научно-исследовательском ветеринарном институте патологии, фармакологии и терапии был разработан новый тканевый препарат аминоселетон, получаемый методом криогенного фракционирования селезенки крупного рогатого скота. Ранее были показаны адаптогенные, стресс-протекторные, антиоксидантные и иммуномодулирующие свойства аминоселетона $(5,6)$.

Оценка генотоксических свойств новых лекарственных средств один из обязательных этапов доклинических исследований при их разработке (7). Химические мутагены широко распространены в окружающей среде и могут становиться причиной возникновения наследственных и врожденных заболеваний, канцерогенеза, старения и митохондриальных болезней $(8,9)$. Мутагенное и канцерогенное действие различных генотоксических веществ также включает образование свободных радикалов, которые перегружают эндогенные системы антиоксидантной защиты, сдерживающие окислительный стресс - одну из причин повреждения ДНК. В целом все антиоксидантные агенты можно рассматривать как потенциальные ингибиторы мутагенеза и канцерогенеза (10).

K веществам, потенциально обладающим антимутагенным действием, относятся препараты растительного или животного происхождения, использование которых связано с их меньшей токсичностью, сродством биологически активных веществ, входящих в состав препаратов и присутствующих в организме животных, доступностью с экономической точки зрения. Однако влияние средств природного происхождения на наследственный аппарат клеток недостаточно изучено. Накопление данных об оценке кластогенных и антимутагенных свойств препаратов, используемых в ветеринарной практике, представляет научный интерес и имеет важное практическое значение. Согласно нашим данным, аминоселетон индуцировал снижение количества малонового диальдегида и метаболитов оксида азота, а также увеличение общей антиокислительной активности сыворотки крови животных. Препарат модулировал ферментативное и неферментативное звено антиоксидантной защиты, например возрастала активность глутатионпероксидазы и каталазы, концентрация витаминов А и Е (11). В связи с этим целесообразно оценить не только безопасность аминоселетона, но и его потенциальные антимутагенные свойства на модели индуцированного циклофосфамидом (ЦФ) мутагенного действия в клетках костного мозга мышей (7). ЦФ - алкилирующий препарат, применяемый в онкологии. Это вещество активируется цитохромом Р-450 в печени, образуя азотистый иприт, который через цепь реакций оказывает алкилирующее действие на ДНК и вызывает образование перекрестных сшивок между цепями ДНК по гуаниновому азотистому основанию, что может быть причиной возникновения мутаций и гибели клеток (12). 
В настоящей работе впервые было выявлено антикластогенное действие тканевого препарата аминоселетона по отношению к клеткам костного мозга мышей, подвергнутых воздействию экспериментального мутагена. Кроме того, было показано сохранение цитогенетической стабильности и митотической активности в клетках костного мозга здоровых животных при применении исследуемого препарата.

Цель работы - оценка влияния аминоселетона на цитогенетическую стабильность клеток костного мозга здоровых и подвергнутых действию экспериментального мутагена мышей, а также выявление антимутагенного свойства препарата применительно к генотоксическому эффекту циклофосфамида с использованием микроядерного теста.

Методика. Эксперименты проводили на беспородных белых мышах (Mus albus officinarum) $(n=60)$ согласно руководству по доклиническим испытаниям препаратов (7). Подопытных животных содержали в стандартных условиях вивария (температура воздуха $18-23{ }^{\circ} \mathrm{C}$, относительная влажность 45-60 \%). Доступ к воде и корму был свободным. Манипуляции в рамках эксперимента проводили в соответствии с положениями Европейской конвенции о защите позвоночных животных, используемых для экспериментов или в иных научных целях (Страсбург, 1986 год, подтверждена в 2006 году). Аминоселетон был получен посредством криофракционирования в виде жидкой суспензии.

Животных разделили на следующие группы: I группа (негативный контроль, $n=12$ ) - введение внутримышечно стерильного изотонического раствора натрия хлорида в объеме 0,2 мл; II группа (позитивный контроль, $n=12$ ) - инъекция внутрибрюшинно 0,2 мл ЦФ («Baxter Oncology GmbH», Германия) в дозе 20,0 мг/кг массы тела (15); III группа $(n=12)-$ внутримышечное однократное введение 0,2 мл аминоселетона в терапевтической дозе 0,5 мл/кг; IV группа $(n=12)-$ внутримышечная однократная инъекция 0,2 мл аминоселетона в 10-кратной терапевтической дозе 5,0 мл/кг; $\mathrm{V}$ группа $(n=6)$ - внутримышечное однократное введение 0,2 мл аминоселетона в дозе 0,5 мл/кг, через 72 ч внутрибрюшинное введение 0,2 мл ЦФ в дозе 20,0 мг/кг; VI группа $(n=6)$ - внутримышечное введение 0,2 мл аминоселетона в дозе 0,5 мл/кг 5-кратно с интервалом 24 ч, через 72 ч после пятой инъекции внутрибрюшинное введение ЦФ аналогично животным из V группы. Эвтаназию животных всех групп проводили посредством передозировки углекислого газа через 24 ч после финальной инъекции.

Для определения количества хромосомных аберраций в костном мозге за 2,5 ч до эвтаназии мышам делали внутрибрюшинную инъекцию 0,025 \% колхицина («ПанЭко», Россия). Далее из бедренных костей с помощью буферного раствора Хенкса $(\mathrm{pH} 7,4)$ шприцем на 5 мл вымывали клетки костного мозга, инкубировали суспензию клеток в 0,075 молярном гипотоническом растворе $\mathrm{KCl}\left(25\right.$ мин при $\left.37^{\circ} \mathrm{C}\right)$, затем фиксировали клетки с помощью охлажденного до $4{ }^{\circ} \mathrm{C}$ ацетоалкоголя (метанол:уксусная кислота - 3:1) и окрашивали по Романовскому-Гимзе. Оценивали митотический индекс (МИ) по числу делящихся клеток на 1000 клеток костного мозга в исследуемых образцах. Подсчитывали число клеток с хромосомными аберрациями в 100 метафазных пластинках на каждое животное (7, 14). Исследовали образцы при увеличении $\times 800$ и $\times 1000$ с помощью микроскопа Биоскоп-1 (ООО «ЛОМО-Микроанализ», Россия). Учитывали одиночные и парные фрагменты, обмены и ахроматические пробелы (гепы), а также клетки с множественными патологиями (7). Исследовали по 6 животных из каждой группы, за исключением V и VI групп. 
Для определения частоты микроядер (микроядерный тест) полихроматофильных эритроцитов (ПХЭ) (15) полученные клетки костного мозга добавляли к 1 \% раствору альбумина в буферном растворе Хенкса $(\mathrm{pH} 7,4)$ (16) и наносили на предметные стекла, далее препараты высушивали, фиксировали метанолом и окрашивали по Романовскому-Гимзе (15). Препараты костного мозга исследовали при увеличении $\times 800$ и $\times 1000$. Устанавливали частоту микроядер на 1000 ПХЭ, всего изучали 2000 ПХЭ на животное. Также учитывали долю ПХЭ на 500 нормохромных эритроцитов (НЭ) и ПХЭ (7). Исследование проводили на 6 животных из каждой группы

Статистическую обработку полученных результатов проводили в программе STADIA 8.0 (НПО «Информатика и компьютеры», Россия). Вычисляли средние значения $(M)$ и стандартные ошибки средних ( $\pm \mathrm{SEM})$. Использовали непараметрический критерий Ван дер Вардена. Различия считались статистически значимыми при $\mathrm{p} \leq 0,05$.

Результаты. Мы проанализировали метафазные пластинки клеток костного мозга мышей исследуемых групп (табл. 1).

1. Частота хромосомных аберраций в клетках костного мозга у беспородных белых мышей (Mus albus officinarum), подвергнутых воздействию различных доз аминоселетона $(n=12, M \pm \mathrm{SEM})$

\begin{tabular}{|c|c|c|c|c|c|c|c|}
\hline \multirow[b]{2}{*}{ Группа } & \multirow[b]{2}{*}{$\begin{array}{l}\text { Метафазы, } \\
\text { шт. }\end{array}$} & \multicolumn{5}{|c|}{ Доля патологий на 100 исследованных клеток, \% } & \multirow{2}{*}{$\begin{array}{l}\text { Общая доля } \\
\text { клеток с па- } \\
\text { тологиями, \% }\end{array}$} \\
\hline & & гепы, \% & $\begin{array}{l}\text { одиночные } \\
\text { фрагменты, \% }\end{array}$ & $\begin{array}{l}\text { парные фраг- } \\
\text { менты, \% }\end{array}$ & обмены, \% & МП, \% & \\
\hline 1 & & & & 0 & & & \\
\hline II & &, 24 & 12 , & $2,8 \pm 0,3$ & & $0,3 \pm 0,23$ & 11,2 \\
\hline III & 6 & $\pm 0,23$ & $0,2 \pm 0,18$ & 0 & 0, & 0 & $1,7 \pm 0,46$ \\
\hline IV & 600 & $1,0 \pm 0,40$ & 0 & 0 & $0,5 \pm 0,24$ & $0,5 \pm 0,24$ & $2,2 \pm 0,59$ \\
\hline
\end{tabular}

П р и м е ч а и е. МП - множественные патологии (более пяти на клетку). Описание групп см. в разделе «Методика».

* Различие с негативным контролем (І группа) статистически значимо при р $\leq 0,05$.

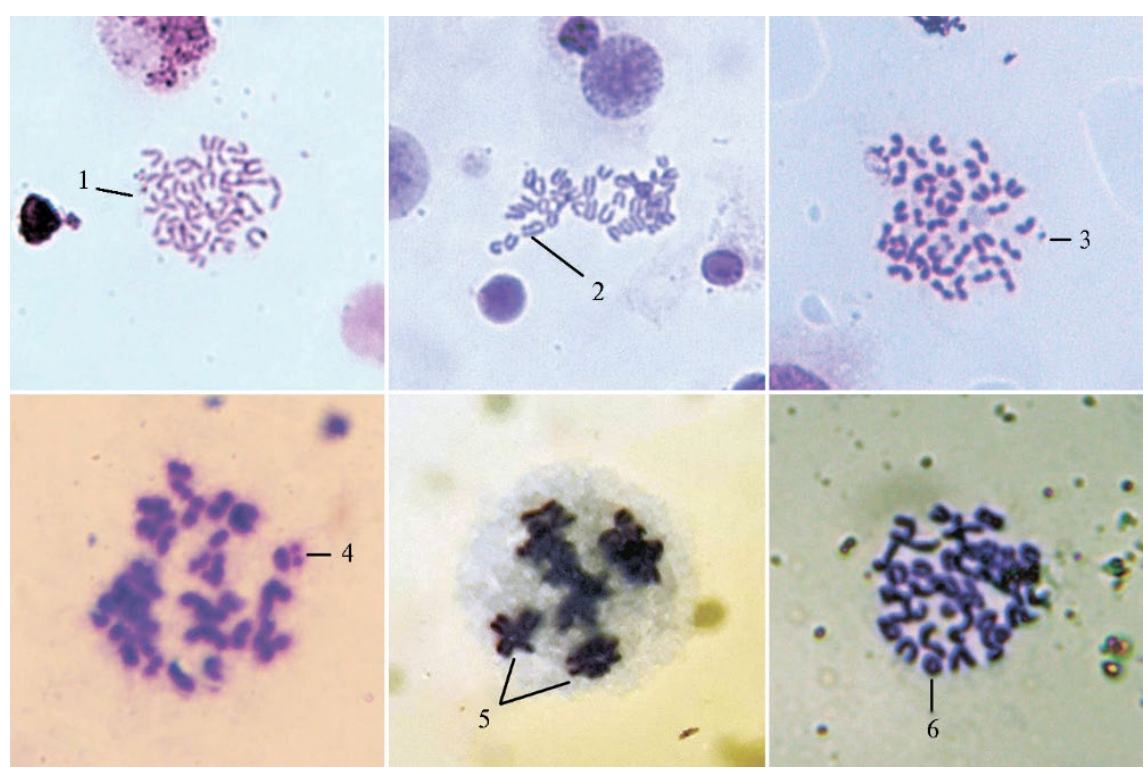

Рис. 1. Микрофотографии метафазных пластинок костного мозга беспородных белых мышей (Mus albus officinarum) при введении внутримышечно стерильного изотонического раствора натрия хлорида в объеме 0,2 мл (негативный контроль): 1 - хромосомы без патологий, 2 - ахроматический пробел (геп), 3 - одиночный фрагмент, 4 - парный фрагмент, 5 - хромосомные и хроматидные обмены, $6-$ кольцевая хромосома (1-3 - увеличение $\times 800,4-6-\times 1000$, Биоскоп-1, ООО «ЛОМО-Микроанализ», Россия).

Однократное внутримышечное введение аминоселетона как в тера- 
певтической $(0,5$ мл/кг), так и в 10 -кратной (5 мл/кг) дозе не индуцировало статистически значимого увеличения доли клеток с хромосомными аберрациями (рис. 1) относительно группы негативного контроля (І группа) через 24 ч (см. табл. 1). Кластогенное действие ЦФ (20 мг/кг), напротив, приводило к 10-кратному повышению частоты клеток с патологиями. Введение аминоселетона также не оказывало влияния на МИ в препаратах костного мозга: в I-IV группах он составлял соответственно 4,0 0,$73 ; 3,1 \pm 0,41$; $3,5 \pm 0,79$ и $3,6 \pm 0,75 \%$.

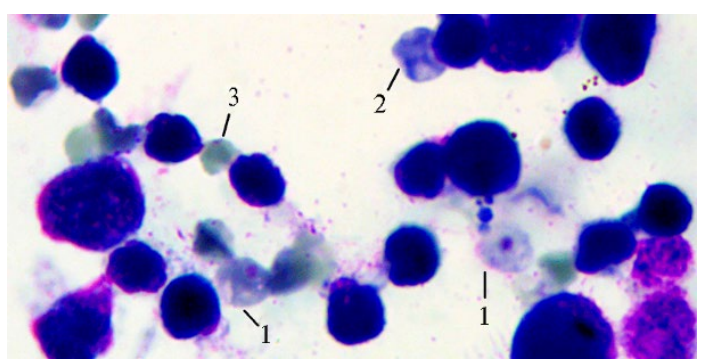

Рис. 2. Микрофотография препарата костного мозга беспородной белой мыши (Mus albus officinarum) при введении внутримышечно стерильного изотонического раствора натрия хлорида в объеме 0,2 мл (негативный контроль): 1 - полихроматофильный эритроцит с микроядром, 2 - полихроматофильный эритроцит, 3 - нормохромный эритроцит (увеличение $\times 1000$, Биоскоп-1, ООО «ЛОМО-Микроанализ», Россия).

Введение аминоселетона в дозах 0,5 и 5 мл/кг массы тела мышей не приводило к изменению частоты микроядер ПХЭ (рис. 2) относительно негативного контроля $(0,23 \pm 0,06 \%)$ (табл. 2). В то же время инъекция ЦФ индуцировала статистически значимое повышение частоты микроядер в ПХЭ у мышей из II, V и VI групп соответственно до 2,2 $\pm 0,21,2,1 \pm 0,26$ и $1,1 \pm 0,09 \%$. Вместе с тем нами было обнаружено антикластогенное действие аминоселетона, который применяли до введения ЦФ 5-кратно в дозе 0,5 мл/кг массы тела (VI группа). Так, частота микроядер в ПХЭ у мышей из VI группы была на 51,3 \% (p $\leq 0,003)$ ниже, чем у животных из II группы, получивших только ЦФ. Однократное введение аминоселетона (V группа) не приводило к статистически значимому снижению частоты микроядер. Также нами была оценена доля ПХЭ в костном мозге мышей, которая может выступать индикатором токсического действия ксенобиотиков (7). Мы не обнаружили статистически значимой разницы в этом показателе между животными всех исследуемых групп, в том числе разницы с позитивным контролем.

2. Частота полихроматофильных эритроцитов (ПХЭ) с микроядрами в костном мозге здоровых беспородных белых мышей (Mus albus officinarum) и животных, получивших инъекцию циклофосфамида, при предварительном введении препарата аминоселетон в различных дозах $(M \pm \mathrm{SEM})$

\begin{tabular}{l|c|c}
\hline \multicolumn{1}{c|}{ Группа } & Доля ПХЭ с микроядрами на 1000 ПХЭ, \% & Доля ПХЭ от (НЭ+ПХЭ), \% \\
\hline I $(n=12)$ & $0,2 \pm 0,06$ & $49,9 \pm 0,93$ \\
II $(n=12)$ & $2,3 \pm 0,21^{\mathrm{a}}$ & $49,0 \pm 1,57$ \\
III $(n=12)$ & $0,2 \pm 0,07$ & $48,9 \pm 0,65$ \\
IV $(n=12)$ & $0,3 \pm 0,11$ & $49,5 \pm 1,43$ \\
V $(n=6)$ & $2,1 \pm 0,26 \mathrm{a}$ & $48,2 \pm 1,79$ \\
VI $(n=6)$ & $1,1 \pm 0,09 \mathrm{a}, \mathrm{b}$ & $50,9 \pm 1,86$ \\
П р и м е ч а н и е. НЭ - нормохромные эритроциты. Описание групп см. в разделе «Методика». \\
a, b Различия соответственно с негативным (І группа) и позитивным (ІІ группа) контролями статистически \\
значимы при р $\leq 0,05$.
\end{tabular}

Ряд препаратов, содержащих экстракт селезенки, применяют в клинической практике в качестве иммуномодуляторов или лекарств для снижения побочных эффектов противоопухолевой терапии $(4,17)$. Полученные нами данные согласуются с информацией об отсутствии мутагенных свойств у других лекарственных средств, имеющих в своей основе селезенку животных. Например, рекомендованный для клинического использования препарат Polyerga $^{\text {тм }}$ («HorFerVit Pharma GmbH», Германия) не проявлял геноток- 
сического действия в тесте Эймса (18). В отличие от полученных нами данных об отсутствии влияния аминоселетона на долю ПХЭ в костном мозге мышей, результаты W. Lu с соавт. (17) свидетельствуют о защитном действии экстракта селезенки новорожденных телят по отношению к мышам с индуцированным циклофосфамидом угнетением кроветворной активности в костном мозге. Это может объясняться значительно большей дозой ЦФ (100 мг/кг массы тела), использованной авторами в модели циклофосфамид-индуцированной супрессии гемопоэза (17).

Обнаруженное нами антикластогенное действие аминоселетона и отсутствие у него мутагенных свойств в некоторой степени подтверждается исследованиями К.А. Дычко с соавт. (19), которые продемонстрировали снижение числа микроядер в эритроцитах при введении экстракта селезенки мышам, подвергшимся воздействию рентгеновских лучей. Авторы полагают, что радиопротекторные эффекты экстракта селезенки были обусловлены его мембраностабилизирующим действием на клетки мышей, которое также было показано нами для аминоселетона (20).

В настоящее время выявлены различные механизмы антимутагенного действия (21). Генотоксичность и цитотоксичность, вызванная ЦФ, в отношении клеток костного мозга может частично нивелироваться за счет антиоксидантной активности (22). Вероятно, антикластогенное действие аминоселетона обусловлено входящим в состав препарата комплексом биологически активных веществ (аминокислоты, фосфолипиды, витамины, олигопептиды, микроэлементы, нуклеиновые кислоты) (20), обладающих антиоксидантным действием (21). Так, аскорбиновая кислота, снижает частоту ПХЭ с микроядрами, индуцированными ЦФ в клетках костного мозга (23). Кроме того, мы показали, что введение аминоселетона увеличивает активность глутатионпероксидазы и приводит к повышению содержания восстановленного глутатиона, количество которого снижается при введении ЦФ и играет важную роль в антиоксидантной защите организма $(11,24)$. Однако антимутагенное действие одних и те же веществ может реализовываться посредством разных механизмов (25).

Поскольку в наших исследованиях аминоселетон проявлял себя как иммуномодулятор клеточного и гуморального звена иммунной системы (6), его антимутагенное действие могло быть обусловлено индукцией синтеза эндогенных цитокинов, обладающих генопротекторным действием, таких как интерферон (8). Так, в ряде работ показано антикластогенное и антиканцерогенное действие интерферонов и их индукторов, по-видимому, за счет активации пострепликативной репарации ДНК $(26,27)$. В исследовании D. Jia с соавт. (28) введение мышам с индуцированной ЦФ иммуносупрессией экстракта селезенки новорожденных телят приводило к увеличению содержания ИНФ- $\alpha$ и ИНФ- $\gamma$ в сыворотке крови, что может свидетельствовать в пользу нашего предположения.

Чувствительность клеток к действию генотоксикантов зависит от поступления в организм витаминов группы В, обладающих антиоксидантными свойствами, микронутриентов и других микроэлементов (таких как магний или цинк), участвующих в репаративных процессах, поддержании клеточного гомеостаза и антиоксидантной защите (8). Их восполнение может оказать системный эффект на антиоксидантую защиту организма. Пролонгированное антикластогенное действие аминоселетона даже спустя 72 ч после финального введения обусловлено длительной активацией антиоксидантной системы при введении препарата (11).

Таким образом, тканевый препарат аминоселетон, получаемый методом криофракционирования из селезенки крупного рогатого скота, в те- 
рапевтической $(0,5$ мл/кг) и высокой $(5,0$ мл/кг) дозах не оказал дестабилизирующего воздействия на цитогенетические характеристики клеток, которое оценивалось по количеству полихроматофильных эритроцитов с микроядрами и хромосомных аберраций в клетках костного мозга беспородных белых мышей. Препарат не повлиял на активность деления клеток, оцениваемую по митотическому индексу. При этом аминоселетон проявил антикластогенный эффект при совместном применении с генотоксикантом циклофосфамидом, снизив частоту встречаемости полихроматофильных эритроцитов с микроядрами в клетках костного мозга мышей на 51,3 \% относительно группы положительного контроля.

\author{
ФГБНУ Всероссийский научно-исследовательский \\ ветеринарный институт патологии, фармакологии \\ и терапии, \\ 394087 Россия, г. Воронеж, ул. Ломоносова, 114-б, \\ e-mail: gvostroilova@mail.ru $₫$, nina_xoxlova@mail.ru,vnivipat@mail.ru, \\ doktor.57@mail.ru, am7d@mail.ru
}

Sel'skokhozyaistvennaya biologiya [Agricultural Biology], 2021, V. 56, № 4, pp. 763-771

\title{
ANTICLASTOGENIC ACTIVITY OF AMINOSELETON UNDER THE EFFECT OF CYCLOPHOSPHAMIDE ON THE BONE MARROW OF MICE
}

\author{
S.V. Shabunin, G.A. Vostroilova ${ }^{\bowtie}$, P.A. Parshin, D.I. Shabanov, N.A. Khokhlova
}

All-Russian Research Veterinary Institute of Pathology, Pharmacology and Therapy, 114-b, ul. Lomonosova, Voronezh, 394087 Russia, e-mail gvostroilova@mail.ru ( $₫$ corresponding author), nina_xoxlova@mail.ru, vnivipat@mail.ru, doktor.57@mail.ru, am7d@mail.ru;

ORCID:

Shabunin S.V. orcid.org/0000-0002-2689-6998

Vostroilova G.A. orcid.org/0000-0002-2960-038X

Parshin P.A. orcid.org/0000-0002-8790-0540

The authors declare no conflict of interests

Received April 29, 2021
Shabanov D.I. orcid.org/0000-0002-1574-1317

Khokhlova N.A. orcid.org/0000-0001-6861-2554

doi: 10.15389 /agrobiology.2021.4.763eng

\section{Abstract}

The tissue drug aminoseleton, designed at the All-Russian Veterinary Research Institute of Pathology, Pharmacology and Therapy, was obtained from the spleen of cattle by cryogenic fractionation. Adaptogenic, membrane stabilizing, stress-protective, antioxidant and immunomodulatory properties of aminoseleton have been already shown. In this work, the anticlastogenic effect of the tissue drug aminoseleton on the bone marrow cells of mice exposed to the experimental mutagen was revealed for the first time. In addition, the preservation of cytogenetic stability and mitotic activity in bone marrow cells of healthy animals was shown when using the study drug. The objective of this work was to assess the effect of aminoseleton on the cytogenetic stability of bone marrow cells in healthy mice and mice exposed to the experimental mutagen, as well as to identify the antimutagenic properties of the drug in relation to the genotoxic effect of cyclophosphamide (CP) using a micronucleus test. The experiments were carried out on outbred white mice (Mus albus officinarum), which were divided into six groups subjected to the following treatments: i) intramuscular administration of sterile isotonic sodium chloride solution in a volume of $0.2 \mathrm{ml}$ (negative control, $n=12$ ); ii) intraperitoneal injection of $0.2 \mathrm{ml}$ of CP (Baxter Oncology GmbH, Germany) at a dose of $20.0 \mathrm{mg} / \mathrm{kg}$ of body weight (positive control, $n=12$ ); iii) intramuscular single injection of $0.2 \mathrm{ml}$ of aminoseleton at a therapeutic dose of $0.5 \mathrm{ml} / \mathrm{kg}(n=12)$; iv) intramuscular single injection of $0.2 \mathrm{ml}$ of aminoseleton at a tenfold therapeutic dose of $5.0 \mathrm{ml} / \mathrm{kg}(n=12) ; \mathrm{v})$ intramuscular single injection of $0.2 \mathrm{ml}$ of aminoseleton at a dose of $0.5 \mathrm{ml} / \mathrm{kg}$ with intraperitoneal injection of $0.2 \mathrm{ml}$ of CP at a dose of $20.0 \mathrm{mg} / \mathrm{kg}$ in $72 \mathrm{~h}(n=6)$; vi) intramuscular fivefold injection of $0.2 \mathrm{ml}$ of aminoseleton at a dose of $0.5 \mathrm{ml} / \mathrm{kg}$ with $24 \mathrm{~h}$ intervals and intraperitoneal administration of CP is similar to animals of other groups $72 \mathrm{~h}$ after the fifth injection $(n=6)$. To determine the amount of chromosomal aberrations in the bone marrow, $2.5 \mathrm{~h}$ before euthanasia, mice were injected intraperitoneally with $0.025 \%$ colchicine (PanEco, Russia). Bone marrow cells were washed out of the femurs using Hanks' buffer solution ( $\mathrm{pH} 7.4)$, the cell suspension was incubated in 0.075 molar hypotonic $\mathrm{KCl}$ solution, then the cells were fixed with acetoalcohol cooled to $4{ }^{\circ} \mathrm{C}$ and stained by Romanowsky-Giemsa procedure. The mitotic index (MI) was assessed by the number of dividing cells per 1000 bone marrow cells. The number of cells with 
chromosomal aberrations was counted in 100 metaphase plates per animal. Single and paired fragments, exchanges and achromatic gaps, as well as cells with multiple pathologies were counted. To study the frequency of micronuclei (micronucleus test) of polychromatophilic erythrocytes (PCE), the obtained bone marrow cells were added to $1 \%$ albumin solution in Hanks' buffer solution ( $\mathrm{pH} 7.4)$ and applied to glass slides, then the samples were dried, fixed with methanol and stained by Romanowsky-Giemsa protocol. The frequency of micronuclei per 1000 PCE was determined; a total of 2000 PCE per animal was studied. The proportion of PCE per 500 normochromic erythrocytes (NE) and PCE was also calculated. The frequency of chromosomal aberrations and micronuclei when administering the drug at the studied doses did not statistically significantly differ from that in animals of their negative control group that was $1.0 \pm 0.40$ and $0.2 \pm 0.06 \%$, respectively. The administration of aminoseleton also had no effect on the mitotic index of bone marrow cells in experimental animals. The course administration of aminoseleton reduced the clastogenic effect of cyclophosphamide, assessed by the number of micronuclei in polychromatophilic erythrocytes of the bone marrow, from $2.3 \pm 0.21 \%$ in mice from the positive control group to $1.0 \pm 0.40 \%$ in animals after a course of aminoseleton injections. Thus, the clastogenic activity of cyclophosphamide decreased by $51.3 \%$ that was probably due to the correction of the prooxidant-antioxidant system of the animal body with the studied drug. A decrease in the number of micronuclei induced by cyclophosphamide in polychromatophilic erythrocytes of the bone marrow indicates the presence of an anticlastogenic potential in aminoseleton.

Keywords: aminoseleton, cyclophosphamide, mutagenicity, anticlastogenic properties, micronuclei, chromosomal aberrations, bone marrow, white mice, polychromatophilic erythrocytes.

\section{REFERENCES}

1. Uchasov D.S., Yarovan N.I., Sein O.B. Vestnik Orlovskogo gosudarstvennogo agrarnogo universiteta, 2013, 1(40): 129-131 (in Russ.).

2. Plenina L.V., Soroka N.F., Chudakov O.P., Tret'yak S.I., Bykadorova L.G., Mit'kovskaya N.P., Golynskii A.B., Maksimovich A.V., Evseenko V.M., Ivanovskii G.L., Alikevich I.N., Drazhina L.S., Grak N.N., Skuratovskaya L.I. Retsept, 2008, 1(57): 104-106 (in Russ.).

3. Fedulova L.V., Vasilevskaya E.R. Myasnye tekhnologii, 2016, 12(168): 37-39 (in Russ.).

4. Chernenkova M.L., Styazhkina S.N., Valinurov A.A. Zhurnal nauchnykh statei zdorov'e $i$ obrazovanie v XXI veke, 2017, 19(8): 161-163 (in Russ.).

5. Vostroilova G.A., Khokhlova N.A., Parshin P.A., Cheskidova L.V., Bryukhova I.V., Sashnina L.Yu., Kantorovich Yu.A., Kartashov S.S. Veterinarnyi farmakologicheskii vestnik, 2018, 2(3): 37-41 (doi: 10.17238/issn2541-8203.2018.2.37) (in Russ.).

6. Shabunin S.V., Vostroilova G.A., Parshin P.A., Khokhlova N.A., Sashnina L.Yu., Mikhailov E.V., Tyurina E.V. Veterinarnaya patologiya, 2018, 3(65): 39-46 (doi: 10.25690/VETPAT.2018.65.20143) (in Russ.).

7. Rukovodstvo po provedeniyu doklinicheskikh issledovanii lekarstvennykh sredstv. Chast' pervaya /Pod redaktsiei A.N. Mironova [Guidelines for conducting preclinical studies of drugs. Part one. A.N. Mironov (ed.)]. Moscow, 2012 (in Russ.).

8. Durnev A.D. Fiziologiya cheloveka, 2018, 44(3): 116-137 (doi: 10.7868/S013116461803013X) (in Russ.).

9. Genetic toxicology: principles and methods. J.M. Parry, E.M. Parry (eds.). Springer, New York, 2012 (doi: 10.1007/978-1-61779-421-6).

10. Delarmelina J.M., Dutra J.C.V., Batitucci Mdo C. Antimutagenic activity of ipriflavone against the DNA-damage induced by cyclophosphamide in mice. Food and chemical toxicology: an international journal published for the British Industrial Biological Research Association, 2014, 65: 140146 (doi: 10.1016/j.fct.2013.12.028).

11. Shabunin S.V., Shakhov A.G., Vostroilova G.A., Parshin P.A., Ermolova T.G., Khokhlova N.A., Bliznetsova G.N. Dostizheniya nauki i tekhniki APK, 2019, 33(7): 71-74 (doi: 10.24411/02352451-2019-10716) (in Russ.).

12. Emadi A., Jones R.J., Brodsky R.A. Cyclophosphamide and cancer: golden anniversary. Nature reviews. Clinical Oncology, 2009, 6(11): 638-647 (doi: 10.1038/nrclinonc.2009.146).

13. Nau H., Spielmann H., Lo Turco Morter C.M., Winckler K., Riedel L., Obe G. Mutagenic, teratogenic and pharmacokinetic properties of cyclophosphamide and some of its deuterated derivatives. Mutation Research/Fundamental and Molecular Mechanisms of Mutagenesis, 1982, 95(23): 105-118 (doi: 10.1016/0027-5107(82)90250-0).

14. Preston R.J., Dean B.J., Galloway S., Holden H., McFee A.F., Shelby M. Mammalian in vivo cytogenetic assays Analysis of chromosome aberrations in bone marrow cells. Mutation Research/Genetic Toxicology, 1987, 189(2): 157-165 (doi: 10.1016/0165-1218(87)90021-8).

15. Hayashi M. The micronucleus test-most widely used in vivo genotoxicity test. Genes and Environment, 2016, 38: 18 (doi: 10.1186/s41021-016-0044-x). 
16. Agarwal D.K., Chauhan L.K. An improved chemical substitute for fetal calf serum for the micronucleus test. Biotechnic \& Histochemistry, 1993, 68(4): 187-188 (doi: 10.3109/10520299309104695).

17. Lu W., Jia D., An S., Mu M., Qiao X., Liu Y., Li X., Wang D. Calf Spleen Extractive Injection protects mice against cyclophosphamide-induced hematopoietic injury through G-CSF-mediated JAK2/STAT3 signaling. Scientific Reports, 2017, 7(1): 8402 (doi: 10.1038/s41598-017-08970-3).

18. Hartleb M., Leuschner J. Toxicological profile of a low molecular weight spleen peptide formulation used in supportive cancer therapy. Arzneimittel-Forschung, 1997, 47(9): 1047-1051.

19. Dychko K.A., Ryzhova G.L., Kravtsova S.S., Kir'yanova N.L., Kuvshinov N.N., Gridneva V.I. Sposob polucheniya sredstva s adaptogennym i protivoluchevym deistviem. Patent RU 2142284 C1 (RF) $M P K^{6}$ A $61 \mathrm{~K}$ 35/28. Tomskii gosudarstvennyi universitet (RF). № 95110155/14. Zayavl. 14.06.1995. Opubl. 10.12.1999 [Method of obtaining a substance with adaptogenic and antiradiation effects. Patent RU 2142284 C1 (RF) MPK $^{6}$ A 61 K 35/28. Tomsk State University (RF). № 95110155/14. Appl. 14.06.1995. Publ. 10.12.1999] (in Russ.).

20. Khokhlova N.A., Lobodina T.E., Grigor'eva N.A., Topol'nitskaya A.V., Fedorova N.M., Panina T.A. Veterinarnyi farmakologicheskii vestnik, 2018, 1(2): 25-30 (doi: 10.17238/issn25418203.2018.1.25) (in Russ.).

21. Goncharova R.I., Kuzhir T.D. Ekologicheskaya genetika, 2005, 3(3): 19-32 (in Russ.).

22. Hosseinimehr S.J., Karami M. Chemoprotective effects of captopril against cyclophosphamideinduced genotoxicity in mouse bone marrow cells. Archives of Toxicology, 2005, 79(8): 482-486 (doi: 10.1007/s00204-005-0655-7).

23. Vijayalaxmi K.K., Venu R. In vivo anticlastogenic effects of L ascorbic acid in mice. Mutation Research/Genetic Toxicology and Environmental Mutagenesis, 1999, 438(1): 47-51 (doi: 10.1016/s1383-5718(98)00161-2).

24. Manda K., Bhatia A.L. Prophylactic action of melatonin against cyclophosphamide-induced oxidative stress in mice. Cell Biology and Toxicology, 2003, 19(6): 367-372 (doi: 10.1023/b:cbto.0000013342.17370.16).

25. De Flora S., Ramel C. Mechanisms of inhibitors of mutagenesis and carcinogenesis. Classification and overview. Mutation Research, 1988, 202(2): 285-306 (doi: 10.1016/0027-5107(88)90193-5).

26. Bolzán A.D., Lacunza E., Bianchi M.S. Effect of recombinant interferon-alpha on streptonigrininduced chromosome aberrations and sister-chromatid exchanges in hamster cells. Mutation Research, 2003, 522(1-2): 127-134 (doi: 10.1016/s0027-5107(02)00304-4).

27. Novitskii V.V., KHlusova M.YU., Ternovaya S.V., Saratikov A.S. Antimutagennoe sredstvo. Patent $R U 2189232 C 2$ (RF) MPK A $61 \mathrm{~K}$ 31/415, A 61 P 43/00. NII farmakologii Tomskogo nauchnogo tsentra RAMN (RF). Sibirskii meditsinskii universitet (RF). № 2000118409/14. Zayavl. 10.07.2000. Opubl. 20.09.2002 [Antimutagenic agent. Patent RU 2189232 C2 (RF) MPK M A $61^{7}$ K 31/415, A 61 P 43/00. Research Institute of Pharmacology of the Tomsk Scientific Center of the Russian Academy of Medical Sciences (RF). Siberian Medical University (RF). № 2000118409/14. Appl. 10.07.2000. Publ. 20.09.2002] (in Russ.).

28. Jia D., Lu W., Wang C., Sun S., Cai G., Li Y., Wang G., Liu Y., Zhang M., Wang D. Investigation on immunomodulatory activity of calf spleen extractive injection in cyclophosphamideinduced immunosuppressed mice and underlying mechanisms. Scandinavian Journal of Immunology, 2016, 84(1): 20-27 (doi: 10.1111/sji.12442). 